University of Nebraska - Lincoln

DigitalCommons@University of Nebraska - Lincoln

\title{
Glyphosate and fungicide effects on Cercospora leaf spot in four glyphosate-resistant sugar beet (Beta vulgaris) varieties
}

\author{
William W. Kirk \\ Michigan State University, kirkw@msu.edu \\ Linda E. Hanson \\ Michigan State University \\ Christy L. Sprague \\ Michigan State University
}

Follow this and additional works at: https://digitalcommons.unl.edu/usdaarsfacpub

Kirk, William W.; Hanson, Linda E.; and Sprague, Christy L., "Glyphosate and fungicide effects on Cercospora leaf spot in four glyphosate-resistant sugar beet (Beta vulgaris) varieties" (2013). Publications from USDA-ARS / UNL Faculty. 1158.

https://digitalcommons.unl.edu/usdaarsfacpub/1158

This Article is brought to you for free and open access by the U.S. Department of Agriculture: Agricultural Research Service, Lincoln, Nebraska at DigitalCommons@University of Nebraska - Lincoln. It has been accepted for inclusion in Publications from USDA-ARS / UNL Faculty by an authorized administrator of DigitalCommons@University of Nebraska - Lincoln. 


\title{
Glyphosate and fungicide effects on Cercospora leaf spot in four glyphosate-resistant sugar beet (Beta vulgaris) varieties
}

\author{
William W. Kirk ${ }^{\mathrm{a}, *}$, Linda E. Hanson ${ }^{\mathrm{a}, \mathrm{b}}$, Christy L. Sprague ${ }^{\mathrm{c}}$ \\ a Department of Plant Pathology, Michigan State University, 35 Plant Biology Building, East Lansing, MI 48824, USA \\ ${ }^{\mathrm{b}}$ USDA-ARS, Michigan State University, East Lansing, MI 48824, USA \\ ${ }^{\mathrm{c}}$ Department of Crop and Soil Sciences, Michigan State University, East Lansing, MI 48824, USA
}

\section{A R T I C L E I N F O}

\section{Article history:}

Received 13 April 2012

Received in revised form

13 September 2012

Accepted 22 September 2012

\section{Keywords:}

Standard-split

RAUDPC

Healthy sugar beet

Harvestable

Strobilurins

Triazole

\begin{abstract}
A B S T R A C T
The potential for improved management of Cercospora leaf spot (CLS), caused by Cercospora beticola, using the herbicide glyphosate in glyphosate-resistant sugar beet varieties was investigated. Controlled field experiments were conducted in 2008 and 2009 to determine if glyphosate and glyphosate-fungicide combinations improved the management of CLS in four commercial varieties of glyphosate-resistant sugar beet. Variety and fungicide main effects were significant for CLS development. However, regardless of the herbicide program, glyphosate or a conventional herbicide program, CLS development was not affected. Therefore, results from of this research indicate that glyphosate and glyphosate-fungicide combinations do not significantly contribute to CLS management.
\end{abstract}

(c) 2012 Elsevier Ltd. All rights reserved.

\section{Introduction}

Glyphosate continues to be a valuable weed management tool for growers with the introduction of glyphosate-resistant crops (Pline-Srnic, 2005; Duke and Powles, 2008). Currently, there are six commercialized glyphosate-resistant crops: soybean [Glycine max (L.) Merr], corn (Zea mays L.), cotton (Gossypium hirsutum L.), canola (Brassica napus L.), alfalfa (Medicago sativa L.) and most recently in 2008 sugar beet (Beta vulgaris L.) (Green, 2009). Michigan sugar beet growers were quick to adopt glyphosate-resistant sugar beet with almost $98 \%$ of Michigan's sugar beet area planted to glyphosate-resistant varieties in 2009 (G. Clark, Agronomist, Michigan Sugar Company, Bay City, MI personal communication).

Glyphosate inhibits the 5-enolpyruvylshikimate-3-phosphate synthase (EPSPS) enzyme, an important component in the shikimic acid pathway (Steinrucken and Amrhein, 1980; Sanogo et al., 2000; Anderson and Kolmer, 2005; Pankey et al., 2005). The shikimic acid pathway occurs in bacteria, fungi, and plants but is not present in most animals (Starcevic et al., 2007). In plants the inhibition of the shikimic acid pathway by glyphosate prevents the production of aromatic amino acids, as well as secondary

\footnotetext{
* Corresponding author. Tel.: +1 517355 4754; fax: +1 5173534940 .

E-mail address: kirkw@msu.edu (W.W. Kirk).
}

compounds, including phytoalexins (Bentley, 1990; Siehl, 1997; Hanson and Gregory, 2002). Some of these secondary compounds are important for plant growth, plant defense against pathogens and herbivores (review Bennett and Wallsgrove, 1994), and plant tolerance under stress. Glyphosate-resistant crops are not injured by glyphosate applications because they contain a CP4-EPSPS gene that exhibits a high level of resistance to glyphosate (Pline et al., 2002).

Cercospora leaf spot (CLS), caused by Cercospora beticola Sacc., is one of the most important foliar diseases of sugar beet (Ruppel, 1986). When severe it can reduce root and sugar yield (Smith and Ruppel, 1971; Shane and Teng, 1992) and may reduce viability of roots in storage (Franc et al., 2001). CLS is managed by a combination of tillage, rotation, host plant resistance and fungicides (Hanson and Panella, 2003; Khan and Smith, 2005; Khan, 2008). The timing of fungicide applications is typically based on weatherdriven models (Windels et al., 1998) such as the BEETcast model which is used in the Michigan sugar beet growing regions [Weather-Innovations (2011) (http://www.weatherinnovations. com/BEETcast.cfm.), Chatham, ON, Canada].

Glyphosate formulations demonstrate anti-fungal activity against some fungi (Bode et al., 1984; Morjan et al., 2002; Pavreena et al., 2007). Different fungi vary in their sensitivity to glyphosate (Meriles et al., 2006) and various glyphosate formulations can have differing effects on fungal growth (Morjan et al., 2002). 
Experiments with glyphosate-resistant wheat (Triticum aestivum L.) indicated that glyphosate can decrease disease severity of leaf rust (Puccinia triticina Eriks.) and stem rust (Puccinia graminis f. sp. tritici Eriks.) when plants were exposed to glyphosate within 21-35 d after rust inoculation (Anderson and Kolmer, 2005). Feng et al. (2005) also found a reduction in leaf and stem rust on wheat, as well as preliminary evidence for reduced Asian soybean rust (Phakopsora pachyrhizi Syd. \& P. Syd.) on soybean with glyphosate in greenhouse experiments, but not with formulation controls, indicating the anti-fungal activity was from the glyphosate active ingredient. Reductions in rust and powdery mildew on glyphosateresistant alfalfa have been reported with glyphosate applications in greenhouse experiments (Foster-Hartnett and Samac, 2008). For soil-borne diseases, some studies have shown no effect on disease severity (Lee et al., 2000; Nelson et al., 2002; Njiti et al., 2003; Barnett et al., 2011, 2012) while other studies have reported potential for increased disease severity (Sanogo et al., 2000; Nelson et al., 2002; Larson et al., 2006).

As well as direct effects of glyphosate on disease severity, there are potentials for interactions with other control measures. A patent application for a synergistic combination of glyphosate and the fungicide flutriafol for disease control have been filed (Noon and Teicher, 2007) and Cercospora leaf spots were one of the disease types cited. However, in a study using Phytophthora megasperma (Drechs.) on soybean, reduced efficacy was reported for the fungicide metalaxyl (Ward, 1984). There is a potential for impacts on disease management if glyphosate, alone or in combination with other chemicals, can influence disease development. Therefore, the objectives of this research were to investigate potential interactions between a conventional herbicide standardsplit program and glyphosate programs with fungicide applications of a standard CLS management program on the development of CLS in four glyphosate-resistant sugar beet varieties.

\section{Materials and methods}

\subsection{Field details}

A field experiment was conducted in 2008 and 2009 in the Saginaw Valley region of Michigan. The 2008 experiment was located in St. Charles, Michigan on a Misteguay silty clay (fine, mixed, semiactive, calcareous, mesic Aeric Endoaquepts) soil with a $\mathrm{pH}$ of 7.8 and $3.0 \%$ organic matter. The 2009 experiment was located in Frankenmuth, Michigan and the soil type was a TappanLondo complex (fine-loamy, mixed, active, calcareous, mesic Typic Endoaquolls) with a pH of 7.7 and $2.4 \%$ organic matter. Experiments followed dry bean in both years. Fields were fall-chisel plowed followed by spring field cultivation twice prior to planting. Fertilizer applications were standard for sugar beet production in Michigan. Meteorological variables were measured with a Campbell weather station located at the farms using a TE525-L rain gauge and a CS215-L temperature and relative humidity sensor connected to a CR200X-Series datalogger (Campbell Scientific, Logan, UH, USA).

\subsection{Varieties and treatments}

The glyphosate-resistant sugar beet varieties Crystal 827RR [ACH827, (BetaSeed, Inc., Shakopee, MN)], Hilleshög 9027RR [H9027, (Syngenta Seeds Inc., Longmont, CO)], Hilleshög 9028RR (H9028), and Hilleshög 9029RR (H9029) were planted 2.5-cm deep in rows spaced $76-\mathrm{cm}$ apart at a population of 122,000 seeds/ha on 25 Apr 2008 and 16 Apr 2009. Plots were six rows wide by $9.1 \mathrm{~m}$ in length. Each variety was planted, one per row, in rows two through five. Rows one and six were a CLS susceptible variety and served as border and spreader rows. Sugar beet varieties selected for this experiment were approved for commercial planting in the Michigan sugar beet growing region and were thought to have varying degrees of CLS tolerance.

The experimental design was a split-split-plot with four replications. The main plot was variety, the sub-plot herbicide treatment, and the sub-sub-plot was fungicide treatment. Herbicide treatments consisted of two glyphosate programs, a standard-split program (standard herbicide program used in non-glyphosateresistant sugar beet), and a hand-weeded control (no herbicide). The glyphosate programs consisted of: 1) glyphosate (Roundup WeatherMAX, Monsanto Co., St. Louis, MO) at $0.84 \mathrm{~kg}$ ae/ha plus ammonium sulfate at $3.62 \mathrm{~kg} / \mathrm{ha}$, applied three times at 2 to 4 -leaf, 4 to 6-leaf, and 6 to 8-leaf sugar beet (referred to as "Glyphosate $\times 3$ ") and 2) glyphosate applied four times ("Glyphosate $\times 4$ ") the same rates and timings as Glyphosate $\times 3$ with an additional glyphosate application at the first fungicide application timing (see below). The standard-split program consisted of a combination of desmedipham plus phenmedipham (Betamix, Bayer CropScience AG, Monheim am Rhein, Germany) each at $180 \mathrm{~g}$ ai/ha, triflusulfuron (UpBeet, E.I. du Pont de Nemours and Co., Crop Protection, Wilmington) at $9 \mathrm{~g}$ ai/ha, clopyralid (Stinger, Dow AgroSciences, Indianapolis, IN) at $104 \mathrm{~g}$ ai/ha, and non-ionic surfactant at $0.25 \% \mathrm{v} / \mathrm{v}$, applied twice when sugar beet was at the cotyledon to 2-leaf and 2 to 4-leaf stages referred to in the results as the "Standard-split program". The rates of desmedipham plus phenmedipham were each increased to $270 \mathrm{~g}$ ai/ha for the second application. All plots were maintained weed-free by hand-weeding throughout the growing season.

Fungicide treatments included: 1) a standard CLS fungicide program and 2) a no fungicide control. The CLS program referred to in the text in as the "CLS-program" consisted of pyraclostrobin at $168 \mathrm{~g}$ ai/ha applied upon attainment of 55 daily risk for disease severity values (DSV) (7 Jul 2008 and 9 Jul 2009); followed by tetraconazole at $114 \mathrm{~g}$ ai/ha on $25 \mathrm{Jul} 2008$ and 4 Aug 2009 (110 DSV); followed by trifloxystrobin at $128 \mathrm{~g}$ ai/ha on 12 Aug 2008 only (18 days after second application). Postemergence (POST) herbicide and fungicide treatments were applied with a tractor-mounted compressed-air sprayer calibrated to deliver $178 \mathrm{~L} / \mathrm{ha}$ at $207 \mathrm{kPa}$ through 10003 AirMix (AirMix 11003, Greenleaf Technologies, Covington, LA) nozzles. Nozzles were spaced $51 \mathrm{~cm}$ apart and were positioned approximately $56 \mathrm{~cm}$ above the sugar beet canopy.

\subsection{Cercospora inoculation}

The sugar beet foliage was inoculated and evaluated in an artificially produced epiphytotic environment. The plots were inoculated on $10 \mathrm{Jul} 2008$ and 9 Jul 2009 with a liquid spore suspension (approximately $1 \times 10^{3}$ spores per $\mathrm{ml}$ ) of $C$. beticola. Inoculum was produced using the method of Ruppel and Gaskill (1971) from dried leaves with CLS symptoms. All leaves had been harvested from field plots not treated with fungicides the previous fall, dried in a drying oven and stored at $7{ }^{\circ} \mathrm{C}$ until use.

\subsection{Data collection and analyses}

Sugar beets were evaluated for herbicide injury $7 \mathrm{~d}$ after the last herbicide application timing on a scale from 0 (no injury) to 100 (plant death). Visual evaluations for disease severity were made on 19 Aug, 26 Aug, 2 Sep and 9 Sep in 2008, and 26 Aug, 2 Sep, 9 Sep and 16 Sep in 2009 with the peak of the epidemic occurring around 2 Sep in 2008 and 9 Sep in 2009 using a disease index (DI) scale where $0=$ no symptoms, $1=$ a few scattered spots, $2=$ spots coalescing or in large numbers on lower leaves only, $3=$ some dieback on lower leaves, but leaves not entirely dead, 4-8 are 
increasing amounts of dead and diseased tissue, $9=$ mostly dead with few remaining living leaves with large dead patches, and $10=$ all leaves dead (Ruppel and Gaskill, 1971). Evaluations were discontinued when regrowth started in non-fungicide controls. Leaf spot evaluations were converted to a single measurement of Relative Area Under the Disease Progress Curve. The rate of leaf spot development with time was calculated initially as the area under the plant progress curve (AUDPC). From this, the relative area under the disease progress curve (RAUDPC) was calculated by modification of the method used to calculate the relative area under the disease progress curve [RAUDPC, (Kirk et al., 2001)], using the following equation:

RAUDPC $=\frac{\sum\left(t_{i+1}-t_{i}\right)^{*}\left(\frac{\mathrm{LS}_{+1}+\mathrm{LS}}{2}\right)}{T_{\text {total }} * 10}$

where $t$ was the time in days after planting and LS was the index of CLS with a maximum value of 10 . As CLS was assessed at various time intervals, the area under emergence progress curve (AUDPC) was calculated by adding the area under the linear progression of the CLS index between consecutive estimations from the first evaluation to the final evaluation. The RAUDPC was calculated by dividing the sum of individual AUDPC values by the maximum AUDPC $(10 \times$ duration of CLS development period $)$.

Sugar beet roots were machine-harvested on 19 Sep 2008 and 24 Sep 2009. Individual plots were weighed and sucrose concentration was determined from samples of 10 beets per plot at the Michigan Sugar Company laboratory in Saginaw, MI.

Data were tested for assumptions of normality and analyzed by analysis of variance procedures using the analysis of variance platform (ANOVA) in the statistical analysis software package JMP (JMP $^{\odot}$ 2008. SAS Institute Inc., SAS Campus Drive, Cary, NC, USA 27513). Treatment means were compared using Fisher's protected LSD at the $P \leq 0.05$ level of significance. Data were presented as main effects when no significant interactions were present.

\section{Results and discussion}

\subsection{Overall analysis}

Field analysis of variance showed that there were significant interactions between results from each year for all measured variables; therefore data from each year were analyzed separately (Table 1).

\subsection{Cercospora leaf spot}

Weather conditions in 2008 and 2009 favored the development of CLS (CLS) with temperature minimum and maximum and precipitation amount within the range that would favor infection

\section{Table 1}

Interaction of year with glyphosate-resistant sugarbeet variety, herbicide and fungicide programs for Cercospora leaf spot development [relative area under the disease progress curve (RAUDPC)], yield, and sugar production [recoverable white sucrose (RWSha)] for Cercospora leaf spot field research conducted in 2008 and 2009.

\begin{tabular}{lrrlll}
\hline Measured variable & $F$ ratio & Prob $>F$ & Year & LSD $_{0.05}$ \\
\cline { 4 - 5 } & & & 2008 & 2009 & \\
\hline $\begin{array}{c}\text { Cercospora leaf spot } \\
\quad \text { (RAUDPC) }\end{array}$ & 27.0854 & $<0.0001$ & 3.7 & 2.8 & 0.3 \\
$\begin{array}{l}\text { Yield (tonne/ha) } \\
\text { RWSha (kg) }\end{array}$ & 9.6594 & 0.0021 & 66.8 & 71.8 & 3.2 \\
\hline
\end{tabular}

and development of CLS after inoculation (Fig. 1A and B). In 2008, conditions were significantly more conducive for CLS and the RAUDPC across all variables on average was 3.7 in comparison to 2.8 in 2009 (Table 1). CLS is favored by periods of high temperature and high relative humidity (Ruppel, 1986) and in both years of the study these conditions prevailed. The severity scaling used in the study (0-10) has been standard for CLS evaluations for several years, however the differential function (RAUDPC) was used to generate a single metric of CLS development to facilitate the analysis of several interacting variables across time. As a generalization, RAUDPC values of less than 3 were generated when CLS severity values ranged from 1 through 4 and those that were greater than 3 from CLS values from 1 through 6 by the end of the evaluation period.

There was a variety by herbicide program interaction for CLS development (RAUDPC) in 2008 (Table 2). Three of the four glyphosate-resistant sugar beet varieties examined did not differ in CLS development among the herbicide programs (Table 3). However, a slight increase in CLS development was observed when the Standard-split program (3.6) or Glyphosate $\times 4$ (3.6) was applied to H9028 compared with the no herbicide control (3.1) when averaged across the CLS fungicide program and no fungicide control. This interaction was not observed in 2009 (Table 2). In fact, the main effect of herbicide program was also not significant. One of our hypotheses was that glyphosate applications would result in a decrease in CLS development compared with the Standard-split

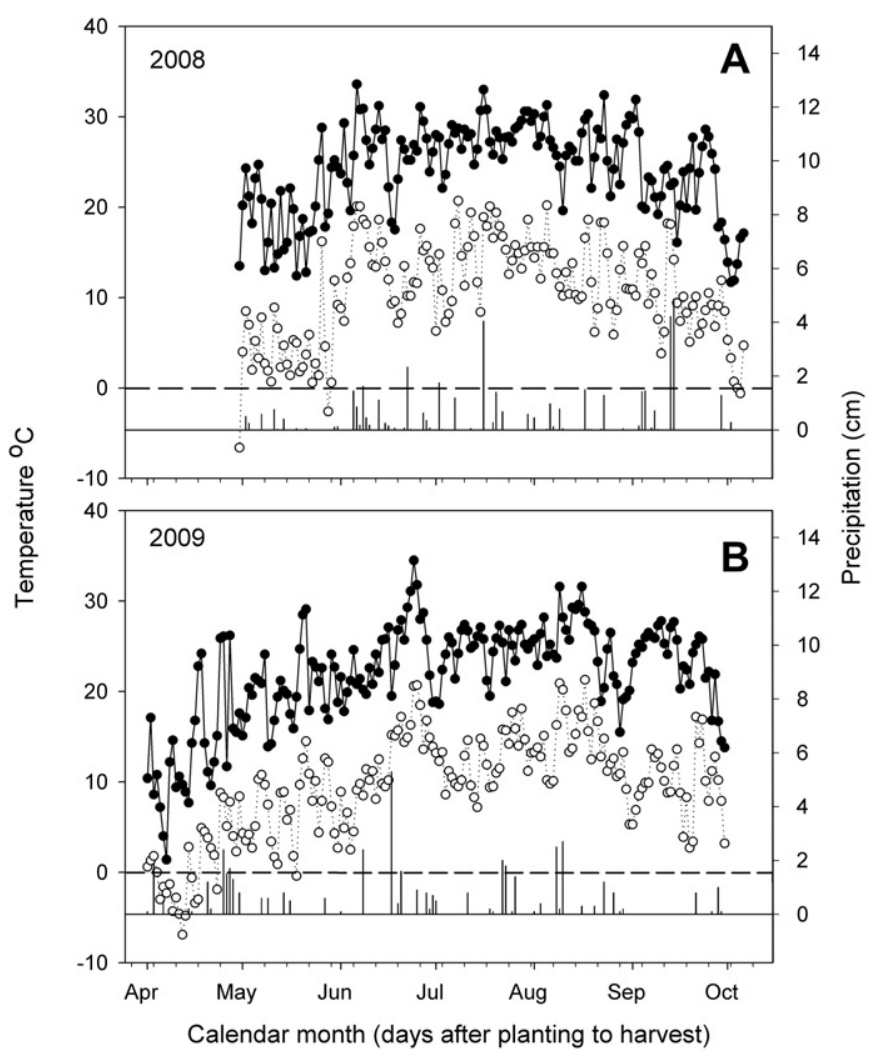

Fig. 1. Maximum (closed circles) and minimum (open circles) daily temperatures $\left({ }^{\circ} \mathrm{C}\right.$ and total daily precipitation [ $\mathrm{cm}$ (vertical bars)] measured at the Saginaw Valley Research and Education Centers in A) 2008 at the St. Charles, Saginaw, MI location and in B) 2009 at the Frankenmuth, Tuscola County, MI location growing seasons from planting to harvest. The minor ticks on the calendar month axis represent successive Sundays in each Month. The dashed horizontal line indicates $0{ }^{\circ} \mathrm{C}$ air temperature. Meteorological variables were measured with a Campbell weather station located at the farms using a TE525-L rain gauge and a CS215-L temperature and relative humidity sensor connected to a CR200X-Series datalogger. 
Table 2

$P$-values for main effects and interactions of variety, herbicide and fungicide programs on Cercospora leaf spot development [relative area under the disease progress curve (RAUDPC)] for Cercospora leaf spot field research conducted in 2008 and 2009.

\begin{tabular}{|c|c|c|c|c|}
\hline \multirow[t]{3}{*}{ Source of variation } & \multirow[t]{3}{*}{$\mathrm{DF}$} & \multicolumn{3}{|c|}{ Cercospora leaf spot development (RAUDPC) } \\
\hline & & $P$-value & & \\
\hline & & 2008 & & 2009 \\
\hline Variety & 3 & $<0.0001$ & \multicolumn{2}{|l|}{$<0.0001$} \\
\hline Herbicide & 3 & 0.0056 & \multicolumn{2}{|l|}{0.0866} \\
\hline Fungicide & 1 & $<0.0001$ & \multicolumn{2}{|l|}{$<0.0001$} \\
\hline Variety*herbicide & 9 & 0.0165 & \multicolumn{2}{|l|}{0.9417} \\
\hline Variety*fungicide & 3 & 0.0838 & \multicolumn{2}{|l|}{0.3421} \\
\hline Herbicide*fungicide & 3 & 0.2688 & \multicolumn{2}{|l|}{0.6272} \\
\hline Variety*herbicide*fungicide & 9 & 0.4440 & \multicolumn{2}{|l|}{0.9925} \\
\hline
\end{tabular}

program and the no herbicide control. This was not the case in our research. The results were in contrast to studies that have shown glyphosate's anti-fungal activity (Bode et al., 1984; Morjan et al., 2002; Pavreena et al., 2007). Anderson and Kolmer (2005) reported that glyphosate could decrease disease severity of leaf and stem rust when wheat plants were exposed to glyphosate within 21-35 d after rust inoculation. Feng et al. (2005) also found a reduction in leaf and stem rust on wheat, as well as, preliminary evidence for reduced Asian soybean rust on soybean with glyphosate applications in greenhouse experiments. The neutral effect observed in this study on CLS from applications of glyphosate, the increase in CLS development on H9028 in 2008 from the Standardsplit program and Glyphosate $4 \times$ was more similar to what has been observed with soil-borne diseases (Sanogo et al., 2000; Nelson et al., 2002; Larson et al., 2006). For example, Larson et al. (2006) reported that a glyphosate-resistant sugar beet variety with

\section{Table 3}

Interaction between variety and herbicide program on Cercospora leaf spot development [relative area under the disease progress curve (RAUDPC)] for Cercospora leaf spot field research conducted in 2008. Data are combined over fungicide programs.

\begin{tabular}{lll}
\hline Variety & Herbicide program & Cercospora leaf spot development \\
\cline { 2 - 3 } & & RAUDPC $(1-10$ scale $)$ \\
\hline ACH872 & No herbicide & $4.5 \mathrm{a}^{\mathrm{b}}$ \\
& Standard-split & $4.5 \mathrm{a}$ \\
& Glyphosate $\times 3$ & $4.4 \mathrm{a}$ \\
$\mathrm{H} 9027$ & Glyphosate $\times 4$ & $4.7 \mathrm{a}$ \\
& No herbicide & $3.2 \mathrm{~cd}$ \\
& Standard-split & $3.3 \mathrm{bcd}$ \\
$\mathrm{H} 9028$ & Glyphosate $\times 3$ & $3.5 \mathrm{bcd}$ \\
& Glyphosate $\times 4$ & $3.5 \mathrm{bcd}$ \\
& No herbicide & $3.1 \mathrm{~d}$ \\
& Standard-split & $3.6 \mathrm{bc}$ \\
$\mathrm{H} 9029$ & Glyphosate $\times 3$ & $3.5 \mathrm{bcd}$ \\
& Glyphosate $\times 4$ & $3.6 \mathrm{bc}$ \\
& No herbicide & $3.4 \mathrm{bcd}$ \\
& Standard-split & $3.4 \mathrm{bcd}$ \\
& Glyphosate $\times 3$ & $3.4 \mathrm{bcd}$ \\
& Glyphosate $\times 4$ & $3.4 \mathrm{bcd}$ \\
\hline
\end{tabular}

a Standard-split herbicide program = desmedipham plus phenmedipham plus triflusulfuron plus clopyralid plus non-ionic surfactant applied twice (rates in text); Glyphosate $\times 3$ and Glyphosate $\times 4=$ glyphosate plus ammonium sulfate applied three times and four times (rates in text), respectively.

b Means followed by same letter are not significantly different at $P \leq 0.05$ (Fisher's Protected LSD). tolerance to Rhizoctonia crown and root rot was more susceptible to an isolate of Rhizoctonia solani AG 2-2 but not to one of AG-4 and also more susceptible to one isolate of Fusarium oxysporum Schlecht but not another after glyphosate was applied.

Averaged across herbicide and fungicide programs, ACH827 was the most susceptible variety to CLS in both years (Table 4). CLS development was similar for other varieties; H9027, H9028, and H9029 which were not different from each other (Table 4). The CLS fungicide program [pyraclostrobin, followed by tetraconazole, followed by trifloxystrobin; (CLS program)] had significantly lower CLS development RAUDPC values in 2008 (2.47) and 2009 (2.05) than the no fungicide controls (4.94 and 4.48; 2008 and 2009, respectively) across all varieties (Table 4 ).

The varieties used in this study were relatively susceptible to CLS and reinforce the requirement for the development and deployment of moderately resistant varieties combined with fungicide rotation to be used in disease control for several years to come (Weiland and Koch, 2004).

\subsection{Yield and sugar production}

Yield and sugar production (RWSha) were lower in 2008 than in 2009 (Table 1). Although these reductions could have been due to climatological factors, the measured increase in CLS development between 2008 and 2009 is also clear and may have been a contributing factor for differences in yield.

There was a significant herbicide by CLS fungicide program interaction for yield and sugar production in 2008 (Table 5). Averaged across all varieties, sugar beet yield ranged from 53.2 to 64.9 tonne ha ${ }^{-1}$ without the use of a CLS fungicide program and from 66.8 to 82.1 tonne ha ${ }^{-1}$ with the CLS fungicide program (Table 6). There was a $13-21$ tonne ha ${ }^{-1}$ yield advantage when the CLS fungicide program was applied in combination with the Standard-split, Glyphosate $\times 3$, and Glyphosate $\times 4$ herbicide programs. The yield advantage for the CLS fungicide program was not apparent in the no-herbicide control. One reason for this observation could be that the no herbicide control tended to yield higher than the three herbicide programs without the use of the CLS fungicide program, particularly for the Standard-split herbicide program. Early in the growing season the Standard-split herbicide program uniformly caused $20 \%$ injury to each of the four sugar beet varieties (data not shown). This early crop response coupled with CLS resulted in an 11.7 tonne ha $^{-1}$ reduction in yield compared with the no herbicide control. Sugar production (RWSha) followed similar trends as yield, with the exception that RWSha was higher

Table 4

Main effect of variety and fungicide program on Cercospora leaf spot development [relative area under the disease progress curve (RAUDPC)] for Cercospora leaf spot field research conducted in 2008 and 2009.

\begin{tabular}{lll}
\hline Main effects & \multicolumn{2}{l}{ Cercospora leaf spot development } \\
\cline { 2 - 3 } & \multicolumn{2}{l}{ RAUDPC $(1-10$ scale $)$} \\
\cline { 2 - 3 } & 2008 & 2009 \\
\hline Variety & $4.5 \mathrm{a}^{\mathrm{a}}$ & $3.8 \mathrm{a}$ \\
ACH827 & $3.4 \mathrm{~b}$ & $3.0 \mathrm{~b}$ \\
H9027 & $3.5 \mathrm{~b}$ & $3.1 \mathrm{~b}$ \\
H9028 & $3.4 \mathrm{~b}$ & $3.2 \mathrm{~b}$ \\
H9029 & & \\
Fungicide program & $\mathrm{b}$ & $4.5 \mathrm{~b}$ \\
No fungicide & $4.9 \mathrm{~b}$ & $2.1 \mathrm{a}$ \\
CLS-program & $2.5 \mathrm{a}$ & \\
\hline
\end{tabular}

a Means followed by same letter are not significantly different at $P \leq 0.05$ (Fisher's Protected LSD).

b CLS-program = three fungicide applications; pyraclostrobin followed by tetraconazole followed by trifloxystrobin (rates in text) 
Table 5

$P$-values for main effects and interactions of variety, herbicide and fungicide programs on yield and sugar production [recoverable white sucrose per hectare (RWSha)] for Cercospora leaf spot field research conducted in 2008 and 2009.

\begin{tabular}{|c|c|c|c|c|c|}
\hline \multirow[t]{3}{*}{ Source of variation } & \multirow[t]{3}{*}{$\mathrm{DF}$} & \multicolumn{4}{|l|}{$P$-value } \\
\hline & & \multicolumn{2}{|l|}{2008} & \multicolumn{2}{|l|}{2009} \\
\hline & & Yield & RWSha & Yield & RWSha \\
\hline Variety & 3 & 0.0002 & 0.0002 & 0.0024 & $<0.0001$ \\
\hline Herbicide & 3 & $<0.0001$ & $<0.0001$ & $<0.0001$ & $<0.0001$ \\
\hline Fungicide & 1 & $<0.0001$ & $<0.0001$ & $<0.0001$ & $<0.0001$ \\
\hline Variety*herbicide & 9 & 0.9298 & 0.7686 & 0.4895 & 0.4124 \\
\hline Variety*fungicide & 3 & 0.0813 & 0.0003 & 0.9708 & 0.7828 \\
\hline Herbicide*fungicide & 3 & 0.0043 & 0.0050 & 0.6958 & 0.7451 \\
\hline Variety*herbicide*fungicide & 9 & 0.9999 & 0.9683 & 0.9992 & 0.9991 \\
\hline
\end{tabular}

for all treatments where the CLS fungicide program was applied (Table 6). Similar to yield, RWSha was greatest when Glyphosate $\times 4$ was applied with the CLS fungicide program. Glyphosate $\times 3$ with the CLS fungicide program also provided similar results.

There was also a significant variety by CLS fungicide program interaction for sugar production (RWSha) in 2008 (Table 5). Regardless of variety, the use of the CLS fungicide program improved RWSha over the no fungicide control (Table 7). When the CLS fungicide program was applied RWSha was greatest with H9028 and ACH827 and lowest with H9029; H9027 was intermediate and not different from the highest or lowest yielding varieties. RWSha results for the varieties were different without the use of the CLS fungicide program. Instead of RWSha being highest for ACH827 it was the lowest. This reinforces the use of effective CLS fungicide programs particularly on sugar beet varieties that do not have a high level of tolerance to CLS. Even though this interaction occurred for RWSha there was not an interaction between variety and CLS fungicide program on sugar beet yield (Table 5). Averaged across all herbicide and fungicide programs, H9028 provided the highest tonnage $\mathrm{ha}^{-1}$ compared with the other three varieties (Table 8), indicating that in 2008 management of CLS may have more of an affect sugar than tonnage.

There were no interactions between sugar beet variety, herbicide program, or fungicide program for yield or sugar production in 2009 (Table 5), indicating that these factors did not influence each other. Averaged across all herbicide and fungicide programs, yield was greatest for $\mathrm{H} 9028$ and ACH827; and lowest for H9027 (Table 8 ). The sugar beet variety H9029 was intermediate, but was

\section{Table 6}

Interaction between herbicide and fungicide programs on yield and sugar production [recoverable white sucrose per hectare (RWSha)] for Cercospora leaf spot field research conducted in 2008. Data are combined over varieties.

\begin{tabular}{llll}
\hline Herbicide program $^{\mathrm{a}}$ & Fungicide program $^{\mathrm{b}}$ & Yield tonnes/ha & RWSha kg/ha \\
\hline No herbicide & No fungicide & $64.9 \mathrm{~cd}^{\mathrm{c}}$ & $6110 \mathrm{de}$ \\
& CLS-program & $71.3 \mathrm{bc}$ & $7265 \mathrm{bc}$ \\
Standard-split & No fungicide & $53.2 \mathrm{e}$ & $4870 \mathrm{f}$ \\
& CLS-program & $66.8 \mathrm{bcd}$ & $6702 \mathrm{~cd}$ \\
Glyphosate $\times 3$ & No fungicide & $60.8 \mathrm{de}$ & $5770 \mathrm{ef}$ \\
& CLS-program & $75.2 \mathrm{ab}$ & $7705 \mathrm{ab}$ \\
Glyphosate $\times 4$ & No fungicide & $60.3 \mathrm{de}$ & $5509 \mathrm{ef}$ \\
& CLS-program & $82.1 \mathrm{a}$ & $8197 \mathrm{a}$ \\
\hline
\end{tabular}

a Standard-split herbicide program = desmedipham plus phenmedipham plus triflusulfuron plus clopyralid plus non-ionic surfactant applied twice (rates in text); Glyphosate $\times 3$ and Glyphosate $\times 4=$ glyphosate plus ammonium sulfate applied three times and four times (rates in text), respectively.

b CLS-program = three fungicide applications; pyraclostrobin followed by tetraconazole followed by trifloxystrobin (rates in text).

c Means followed by same letter are not significantly different at $P \leq 0.05$ (Fisher's Protected LSD).
Table 7

Interaction between variety and fungicide programs on sugar production [recoverable white sucrose per hectare (RWSha)] for Cercospora leaf spot field research conducted in 2008. Data are combined over herbicide programs.

\begin{tabular}{lll}
\hline Variety & Fungicide program $^{\mathrm{a}}$ & RWSha kg/ha \\
\hline ACH827 & No fungicide & $4928 \mathrm{e}^{\mathrm{b}}$ \\
& CLS-program & $7917 \mathrm{a}$ \\
$\mathrm{H} 9027$ & No fungicide & $5934 \mathrm{~cd}$ \\
& CLS-program & $7327 \mathrm{ab}$ \\
$\mathrm{H} 9028$ & No fungicide & $6006 \mathrm{~cd}$ \\
& CLS-program & $7945 \mathrm{a}$ \\
$\mathrm{H} 9029$ & No fungicide & $5391 \mathrm{de}$ \\
& CLS-program & $6680 \mathrm{bc}$ \\
\hline
\end{tabular}

${ }^{\text {a }}$ CLS-program = three fungicide applications; pyraclostrobin followed by tetraconazole followed by trifloxystrobin (rates in text).

${ }^{b}$ Means followed by same letter are not significantly different at $P \leq 0.05$ (Fisher's Protected LSD).

Table 8

Main effect of variety (2008) on yield and variety, herbicide and fungicide programs (2008 \& 2009) on yield and sugar production [recoverable white sucrose per hectare (RWSha)] for Cercospora leaf spot field research.

\begin{tabular}{|c|c|c|c|}
\hline \multirow[t]{2}{*}{ Main effects } & \multirow{2}{*}{$\frac{2008}{\text { Yield tonnes/ha }}$} & \multicolumn{2}{|l|}{2009} \\
\hline & & Yield tonnes/ha & RWSha kg/ha \\
\hline \multicolumn{4}{|l|}{ Variety } \\
\hline ACH827 & $64.2 \mathrm{~b}^{\mathrm{a}}$ & $73.9 \mathrm{a}$ & $9351 \mathrm{a}$ \\
\hline H9027 & $66.4 \mathrm{~b}$ & $67.1 \mathrm{~b}$ & $8118 \mathrm{c}$ \\
\hline H9028 & $72.5 \mathrm{a}$ & $76.2 \mathrm{a}$ & $9139 a b$ \\
\hline H9029 & $64.3 \mathrm{~b}$ & $70.0 \mathrm{ab}$ & 8471 bc \\
\hline \multicolumn{4}{|c|}{ Herbicide program $^{\mathrm{b}}$} \\
\hline No herbicide & & $57.6 \mathrm{~b}$ & $6986 \mathrm{~b}$ \\
\hline Standard-split & & $76.2 \mathrm{a}$ & $9140 \mathrm{a}$ \\
\hline Glyphosate $\times 3$ & & $75.8 \mathrm{a}$ & 9502 a \\
\hline Glyphosate $\times 4$ & & $77.7 \mathrm{a}$ & 9452 a \\
\hline \multicolumn{4}{|c|}{ Fungicide program $^{c}$} \\
\hline No fungicide & & $67.5 \mathrm{~b}$ & 7977 b \\
\hline CLS-program & & $76.1 \mathrm{a}$ & 9563 a \\
\hline
\end{tabular}

${ }^{\text {a }}$ Means followed by same letter are not significantly different at $P \leq 0.05$ (Fisher's Protected LSD).

b Standard-split herbicide program = desmedipham plus phenmedipham plus triflusulfuron plus clopyralid plus non-ionic surfactant applied twice (rates in text) Glyphosate $\times 3$ and Glyphosate $\times 4=$ glyphosate plus ammonium sulfate applied three times and four times (rates in text), respectively.

${ }^{c}$ CLS-program = three fungicide applications; pyraclostrobin followed by tetraconazole followed by trifloxystrobin (rates in text).

not different from the highest or lowest yielding varieties. Sugar production (RWSha) followed similar trends, however H9028 (9139 $\mathrm{kg} \mathrm{ha}^{-1}$ ) was not different than the highest sugar producing variety ACH827 (9351 kg ha ${ }^{-1}$ ) and H9029 (8471 kg ha $\left.{ }^{-1}\right)$ and H9029 was not different than the lowest sugar producing variety H9027 (8118 $\mathrm{kg} \mathrm{ha}^{-1}$; Table 8).

Averaged across all varieties and fungicide programs, all herbicide programs had greater yield and produced more sugar than the no-herbicide control in 2009 (Table 8). One possible explanation for the differences in yield was that the act of hand-weeding in the noherbicide control may have increased compaction from the traffic of the hand-weeding crew resulting in lower yields and sugar production. Averaged across all varieties and herbicide programs, the use of the CLS fungicide program improved sugar beet yield by 8.6 tonne ha ${ }^{-1}$ and RWSha by $1586 \mathrm{~kg} \mathrm{ha}^{-1}$ (Table 8 ).

\section{Conclusions}

Clearly, the herbicide programs had no positive or negative impact on yield or sugar production in this research and were in concurrence with similar studies on sugar beet conducted in Michigan on Rhizoctonia crown and root rot in glyphosate-resistant 
sugar beet (Barnett et al., 2011, 2012). The CLS fungicide program in our experiments on CLS systematically improved yield and sugar quality parameters in both years and, considering the high level of disease pressure and the efficacy of the fungicides used, this was not unexpected.

\section{Acknowledgments}

The authors would like to thank Gary Powell, Tom Goodwill, Tim Duckert, and Paul Horny for assistance with this project. This research was funded, in part, by the Michigan AgBioResearch GREEEN (Generating Research and Extension to meet Economic and Environmental Needs) and the Michigan Sugar Company.

Mention of trade names or commercial products in this publication is solely for the purpose of providing specific information and does not imply recommendation or endorsement by the U.S. Department of Agriculture.

\section{References}

Anderson, J.A., Kolmer, J.A., 2005. Rust control in glyphosate tolerant wheat following application of the herbicide glyphosate. Plant Dis. 89, 1136-1142.

Barnett, K.A., Sprague, C.L., Kirk, W.W., Hanson, L.E., 2011. Lack of interaction between glyphosate and fungicide treatments on Rhizoctonia crown and root rot in glyphosate-resistant sugarbeet. J. Sugar Beet Res. 48, 1-16.

Barnett, K.A., Sprague, C.L., Kirk, W.W., Hanson, L.E., 2012. Influence of glyphosate on Rhizoctonia crown and root rot (Rhizoctonia solani) in glyphosate-resistant sugarbeet. Weed Sci. 60, 113-120.

Bennett, R.N., Wallsgrove, R.M., 1994. Tansley Review No. 72. Secondary metabolites in plant defence mechanisms. New Phytol. 127, 617-633.

Bentley, R., 1990. The shikimate pathway: a metabolic tree with many branches. In: Fasman, G.D. (Ed.), Crit Rev Biochem Mol. CRC Press, Boca Raton, FL, USA pp. 307-384.

Bode, R., Melo, C., Birnbaum, D., 1984. Mode of action of glyphosate in Candida maltosa. Arch. Microbiol. 140, 83-85.

Duke, S.O., Powles, S.B., 2008. Glyphosate: a once-in-a-century herbicide. Pest Manag. Sci. 64, 319-325.

Feng, P.C.C., Baley, G.J., Clinton, W.P., Bunkers, G.J., Alibhai, M.F., Paulitz, T.C., Kidwell, K.K., 2005. Glyphosate inhibits rust disease in glyphosate-resistantwheat and soybean. PNAS 102, 17290-17295.

Foster-Hartnett, D., Samac, D.A., 2008. Effect of glyphosate on foliar diseases in Roundup Ready alfalfa. Phytopathology 98, S54 (abstract)

Franc, G.D., Harveson, R.M., Kerr, E.D., Jacobsen, B.J., 2001. Disease management. In: Wilson, R.G., Smith, J.A., Miller, S.D. (Eds.), Sugarbeet Production Guide University of Nebraska Institute of Agriculture and Natural Resources, Lincoln, Nebraska, USA, pp. 131-160.

Green, J.M., 2009. Evolution of glyphosate-resistant crop technology. Weed Sci. 57, $108-117$.

Hanson, A.D., Gregory, J.F., 2002. Synthesis and turnover of folates in plants. Curr. Opin. Plant Biol. 5, 244-249.

Hanson, L.E., Panella, L., 2003. Disease control in sugar beet. Int. Sugar. J. 105, 60-68.

Khan, M.F., 2008. Evaluating strategies for managing Cercospora leaf spot of sugarbeet. Phytopathology 98, S80 (abstract).

Khan, M.F.R., Smith, L.J., 2005. Evaluating fungicides for controlling Cercospora leaf spot on sugar beet. Crop Prot. 24, 79-86.

Kirk, W.W., Felcher, K.J., Douches, D.S., Coombs, J., Stein, J.M., Baker, K.M., Hammerschmidt, R., 2001. Effect of host plant resistance and reduced rates and frequencies of fungicide application to control potato late blight. Plant Dis. 85, 1113-1118.
Larson, R.L., Hill, A.L., Fenwick, A., Kniss, A.R., Hanson, L.E., Miller, S.D., 2006. Influence of glyphosate on Rhizoctonia and Fusarium root rot in sugar beet. Pest Manag. Sci. 62, 1182-1192.

Lee, C.D., Penner, D., Hammerschmidt, R., 2000. Influence of formulated glyphosate and activator adjuvants on Sclerotinia sclerotiorum in glyphosate-resistant and -susceptible Glycine max. Weed Sci. 48, 710-715.

Meriles, J.M., Vargas Gil, S., Haroz, R.J., March, G.J., Guzman, C.A., 2006. Glyphosate and previous crop residue effect on deleterious and beneficial soil-borne fungi from a peanut-corn-soybean rotation. J. Phytopathol. 145, 309-316.

Morjan, W.E., Pedigo, L.P., Lewis, L.C., 2002. Fungicidal effects of glyphosate and glyphosate formulations on four species of entemopathogenic fungi. Environ. Entomol. 31, 1206-1212.

Nelson, K.A., Renner, K.A., Hammerschmidt, R., 2002. Cultivar and herbicide selection affects soybean development and the incidence of Sclerotinia stem rot. Agron. J. 94, 1270-1281.

Njiti, V.N., Myers Jr., O., Schroeder, D., Lightfoot, D.A., 2003. Roundup Ready soybean: glyphosate effects on Fusarium solani root colonization and sudden death syndrome. Agron. J. 95, 1140-1145.

Noon, R.A., Teicher, H.B., 2007. Synergistic Combination of a Glyphosate Herbicide and a Triazole Fungicide. US Patent Application No 20070010401, filed 06/21/ 2006 and Published 01/11/2007.

Pankey, J.H., Griffin, J.L., Colyer, P.D., Schneider, R.W., Miller, D.K., 2005. Preemergence herbicide and glyphosate effects on seedling diseases in glyphosateresistant cotton. Weed Technol. 19, 312-318.

Pavreena, R., Naseema, A., George, S., 2007. Effect of herbicides on Fusarium pallidoroseum - a potential biocontrol agent of water hyacinth [Eichhornia crassipes (Mart.) Solms]. J. Trop. Agric. 45, 55-57.

Pline, W.A., Viator, R., Wilcut, J.W., Edmisten, K.L., Thomas, J., Wells, R., 2002. Reproductive abnormalities in glyphosate-resistant cotton caused by lower CP4-EPSPS levels in the male reproductive tissue. Weed Sci. 50, 438-447.

Pline-Srnic, W., 2005. Technical performance of some commercial glyphosateresistant crops. Pest Manag. Sci. 61, 225-234.

Ruppel, E.G., 1986. Cercospora leaf spot. In: Whitney, E.D., Duffus, J.E. (Eds.), Compendium of Beet Diseases and Insects. APS Press, St Paul, Minnesota, USA, pp. 8-9.

Ruppel, E.G., Gaskill, J.O., 1971. Techniques for evaluating sugarbeet for resistance to Cercospora beticola in the field. J. Am. Soc. Sugar Beet Technol. 16, 384-389.

Sanogo, S., Yang, X.B., Scherm, H., 2000. Effects of herbicides on Fusarium solani f. sp. glycines and development of sudden death syndrome in glyphosate-tolerant soybean. Phytopathology 90, 57-66.

Shane, W.W., Teng, P.S., 1992. Impact of Cercospora leaf spot on root weight, sugar yield and purity. Plant Dis. 76, 812-820.

Siehl, D.L., 1997. Inhibitors of EPSP synthase, glytamine synthase and histidine synthesis. In: Roe, R.M. (Ed.), Herbicide Activity: Toxicology, Biochemistry and Molecular Biology. IOS Press, Amsterdam, Netherlands, Amsterdam, Netherlands, pp. 37-67.

Smith, G.A., Ruppel, E.G., 1971. Cercospora leaf spot as a predisposing factor in storage rot of sugar beet. Phytopathology 61, 1485-1487.

Starcevic, A., Shamima, A., Dunlap, W.C., Schick, J.M., Hranueli, D., Cullum, J., Long, P.F., 2007. Enzymes of the shikimic acid pathway encoded in the genome of a basal metazoan, Nematostella vectensis, have microbial origins. PNAS 105, 2533-2537.

Steinrucken, J., Amrhein, N.B., 1980. The herbicide glyphosate is a potent inhibitor of 5-enolpyruvylshikimic acid-2-phosphate synthase. Biochem. Biophys. Res. Commun. 94, 1207-1212.

Ward, E.W.B., 1984. Suppression of metalaxyl activity by glyphosate: evidence that host defense mechanisms contribute to metalaxyl inhibition of Phytophthora megasperma f. sp. glycinea in soybeans. Physiol. Plant Pathol. 25, 381-386.

Weather-Innovations, 2011. BEETcast. Chatham, ON, Canada. http://www.weath erinnovations.com/BEETcast.cfm.

Weiland, J., Koch, G., 2004. Sugarbeet leaf spot disease (Cercospora beticola Sacc.). Mol. Plant Pathol. 5, 157-166.

Windels, C.E., Lamey, H.A., Dave, H., Widner, J., Knudsen, T., 1998. A Cercospora leaf spot model for sugar beet in practice by an industry. Plant Dis. 82, 716-726. 